\title{
Synthetical Evaluation of the Eco-environment Sustainability Based on Grey Correlation Degree in Hebei Province
}

\author{
Nannan Shan \\ Hebei University of science and technology \\ Shijiazhuang,China \\ E-mail: 15903219372@163.com
}

\author{
Ran Hou \\ Hebei University of science and technology \\ Shijiazhuang,China \\ E-mail: 402348253@qq.com
}

\begin{abstract}
In recent years, with the seriously ecological pollution, environmental problem has become one of the concerns about the topic. Hebei province is a region of high energy consumption, high pollution, in order to guarantee the quality of people's living environment, the ecological environment in Hebei province sustainable research is imperative. Through the evaluation and analysis of ecological environment of Hebei province, promote the sustainable development of the ecological environment in the region. This paper selects indicators for the sustainable development of ecological environment, establishes the suitable index system, combines with the data which are premised on the Chinese Environment Yearbook 2009-2013, and applies the gray correlation degree analysis method to calculate the index correlation coefficient and weighted incidence degree. Finally, it can get the index ranking of sustainable ability of ecological environment of Hebei Province for nearly five years. Combining with source data analysis and comparison results to find the reason for ecological environment advantages and disadvantage. Finally,according to the conclusion that ecological environment is unsustainable to put forward countermeasures. This study provides a theoretical guidance to strengthen the construction of ecological environment, to promote the harmonious development of economy, society and the environment.
\end{abstract}

Keywords-weighted incidence degree;grey correlation analysis;ecological environment;sustainable ability;index system

\section{INTRODUCTION}

Correctly handling the relationship between economic development and environmental protection is one of the key issues in the realization of the sustainable economic development. The realization of sustainable development is not only to achieve economic and social sustainable development, but also to achieve the sustainable development of ecological environment. Based on the pressure-state-response (PSR) indicator framework model, the scholar Mei Jing (2009) used the full permutation polygon synthesis index method and regression analysis method to evaluate the sustainable development capacity in Jiangsu region[1]; Zhao Duo(2003) used principal component analysis method from the potentiality of natural resources, environmental quality, ecological environment protection, construction of ecological environment and the ecological environment management six main aspects to establish evaluation index system of sustainable development of ecological environment in Zhejiang province and analyze it[2]; while Zhang Pengtao (2013)evaluated the sustainable ability of a region's ecology, the ecological footprint model is used to calculate its ecosystem carrying capacity and ecological footprint[3]. By taking Hebei Province as example and using the gray correlation degree analysis method, this paper analyzes the sustainable development of the regional ecological environment.

\section{SUSTAINABILITY EVALUATION INDEX SYSTEM OF ECOLOGICAL ENVIRONMENT}

\section{A. The Principle of Indicators Selecting}

The evaluation index system is an organic with certain hierarchical structure whole composed of evaluation indexes with multiple connection and interaction. Basic principles of sustainable development capacity of 
ecological environment evaluation index establishing in this paper are operable, comparable, representative, independence and completeness.[4]

B. The Establishment of the Index System[5][6]

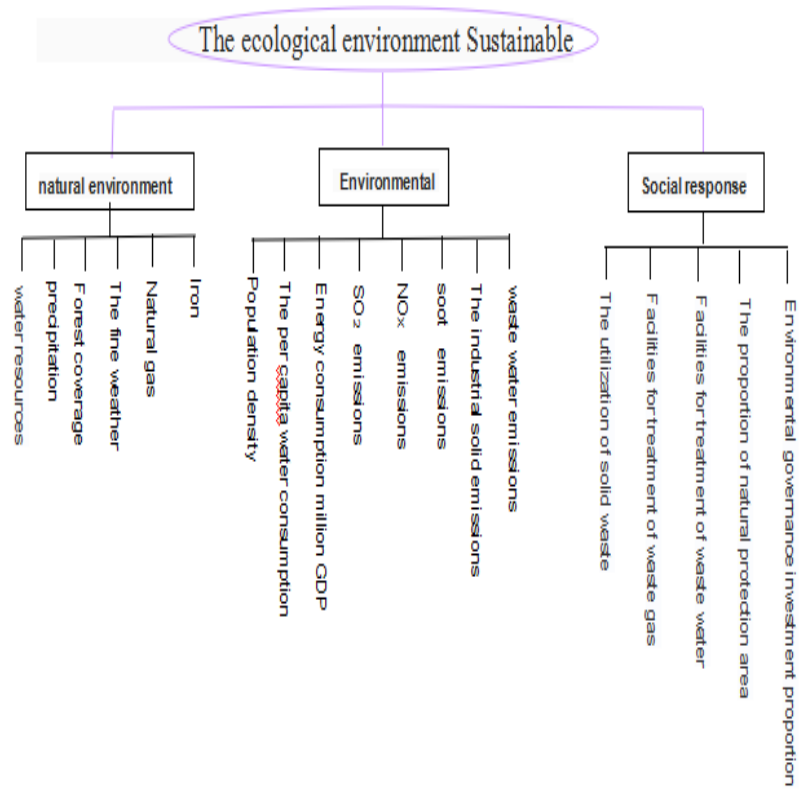

\section{SUMMARY OF GREY CORRELATION} ANALYSIS METHOD

\section{A. Evaluation of the Method}

The advantages of the correlation degree analysis method are clear thinking and does not too much demand on the amount of data, which can largely reduce the losses caused by the information asymmetry, the data can be analyzed more with less, less workload; the main disadvantage of this method is that it required to determine the optimal values of each index by the current.The subjectivity is too strong, and some indicators is difficult to determine the optimal value.

\section{B. The Grey Relational Analysis Model}

If the number of performance index is $\mathrm{k}$, and $\mathrm{i}$ years of data, it can establish the index series, denoted as $\mathrm{Xi}$ (K)[9],

$$
\mathrm{Xi}(\mathrm{k})=\{\mathrm{xi}(1), \mathrm{xi}(2), \ldots, \mathrm{xi}(\mathrm{n})\} \quad(\mathrm{i}=1,2, \ldots, \mathrm{m} ;
$$

$\mathrm{k}=1,2, \ldots, \mathrm{n})$

Processing the relative method makes the index values dimensionless process. First to define a standard value of evaluation indexes, then to calculate the ratio of index value and standard value.

Association analyses should formulate reference data columns. Based on the dimensionless results to confirm the reference sequence, and reference data series is often denoted as $\mathrm{X} 0$, generally expressed as:

$$
\mathrm{X} 0(\mathrm{k})=\{\mathrm{x} 0(1), \mathrm{x} 0(2), \ldots, \mathrm{x} 0(\mathrm{n})\}
$$

Determining the association coefficient and correlation attention

$\xi_{i}(\kappa)=\frac{\min _{i} \min _{k}\left|x_{0}(k)-x_{i}(k)\right|+\zeta \max _{i} \max _{k}\left|x_{0}(k)-x_{i}(k)\right|}{\left|x_{0}(k)-x_{\mathrm{i}}(k)\right|+\zeta \max _{i} \max _{k}\left|x_{0}(k)-x_{i}(k)\right|}$

In the formula, $\xi_{i}(\kappa)$ is the relative difference of $\mathrm{k}$

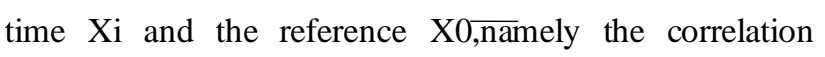
coefficient of $\mathrm{Xi}$ to $\mathrm{X} 0$ at k moment. $\zeta$ is resolution ratio, which is functional to improve the correlation coefficient between the significant difference. $\zeta \in[0,1]$, usually $\zeta=0.5$.

$$
r_{i}=\sum_{k=1}^{n} W_{k} \xi_{i}(k)
$$

The $r_{i}$ is grey weighted correlation degree for the evaluation object $\mathrm{i}$ to the ideal object, and Wk represents the weight of index.

Obviously, the bigger the correlation degree is, the corresponding index is closer to optimal, the sustainable capacity is more.

\section{GREY CORRELATION ANALYSIS OF SUSTAINABLE DEVELOPMENT INDEX SYSTEM}

\section{A. The Index Data Collection and Processing}

By reference to the Chinese Environmental Statistic Yearbook, collect raw data of indexes, and the relative methods are used to deal with the dimensionless of original indexes data, the results as shown in Table I . 
TABLE I. THE ECOLOGICAL ENVIRONMENT OF HEBEI PROVINCE SUSTAINABLE EVALUATION INDEX

\begin{tabular}{|c|c|c|c|c|c|c|}
\hline Index & 2008 & 2009 & 2010 & 2011 & 2012 & $\begin{array}{r}\text { Total } \\
\text { weigh }\end{array}$ \\
\hline Water & 0.683 & 0.599 & 0.589 & 0.667 & 1 & 0.037 \\
\hline resources & 7 & 6 & 8 & 5 & & \\
\hline precipitation & 0.49 & 0.763 & 0.867 & 0.813 & 1 & 0.007 \\
\hline Forest & 0.820 & 0.861 & 0.861 & 0.963 & 1 & 0.007 \\
\hline coverage & 6 & 1 & 1 & & & \\
\hline The fine & 0.952 & 0.982 & 0.991 & 0.997 & 1 & 0.013 \\
\hline weather days & 9 & 4 & 2 & 1 & & \\
\hline Natural gas & 0.845 & 0.818 & 1 & 0.927 & 0.877 & 0.021 \\
\hline Iron ore & 1 & 0.817 & 0.858 & 0.612 & 0.555 & 0.021 \\
\hline $\begin{array}{c}\text { Population } \\
\text { density }\end{array}$ & 1 & $\begin{array}{c}0.994 \\
6\end{array}$ & $\begin{array}{c}0.971 \\
1\end{array}$ & $\begin{array}{c}0.966 \\
1\end{array}$ & $\begin{array}{c}0.958 \\
5\end{array}$ & 0.033 \\
\hline $\begin{array}{c}\text { The per capita } \\
\text { water }\end{array}$ & $\begin{array}{c}0.752 \\
8\end{array}$ & $\begin{array}{c}0.792 \\
7\end{array}$ & $\begin{array}{c}0.821 \\
2\end{array}$ & 1 & 1 & 0.054 \\
\hline $\begin{array}{c}\text { Energy } \\
\text { consumption } \\
\text { million GDP }\end{array}$ & $\begin{array}{c}0.960 \\
4\end{array}$ & $\begin{array}{c}0.973 \\
2\end{array}$ & $\begin{array}{c}0.987 \\
5\end{array}$ & $\begin{array}{c}0.990 \\
4\end{array}$ & 1 & 0.054 \\
\hline $\begin{array}{c}\mathrm{SO}_{2} \\
\text { emissions }\end{array}$ & $\begin{array}{c}0.917 \\
5\end{array}$ & $\begin{array}{c}0.984 \\
8\end{array}$ & 1 & $\begin{array}{c}0.873 \\
9\end{array}$ & $\begin{array}{c}0.920 \\
1\end{array}$ & 0.099 \\
\hline $\begin{array}{c}\mathrm{NO}_{\mathrm{X}} \\
\text { emissions }\end{array}$ & $\begin{array}{c}0.976 \\
5\end{array}$ & 1 & 0.883 & 0.553 & $\begin{array}{c}0.565 \\
6\end{array}$ & 0.099 \\
\hline $\begin{array}{c}\text { soot } \\
\text { emissions }\end{array}$ & $\begin{array}{c}0.943 \\
4\end{array}$ & $\begin{array}{c}0.980 \\
4\end{array}$ & 1 & $\begin{array}{c}0.378 \\
1\end{array}$ & $\begin{array}{c}0.404 \\
6\end{array}$ & 0.099 \\
\hline $\begin{array}{l}\text { The industrial } \\
\text { solid emissions }\end{array}$ & 1 & $\begin{array}{c}0.899 \\
6\end{array}$ & $\begin{array}{c}0.623 \\
9\end{array}$ & $\begin{array}{c}0.438 \\
1\end{array}$ & $\begin{array}{c}0.433 \\
8\end{array}$ & 0.099 \\
\hline $\begin{array}{l}\text { waste water } \\
\text { emissions }\end{array}$ & 1 & $\begin{array}{c}0.909 \\
6\end{array}$ & $\begin{array}{c}0.849 \\
1\end{array}$ & $\begin{array}{c}0.800 \\
3\end{array}$ & 0.729 & 0.099 \\
\hline $\begin{array}{l}\text { The utilization } \\
\text { of solid waste }\end{array}$ & $\begin{array}{c}0.908 \\
9\end{array}$ & 1 & $\begin{array}{c}0.798 \\
9\end{array}$ & $\begin{array}{c}0.587 \\
3\end{array}$ & $\begin{array}{c}0.536 \\
5\end{array}$ & 0.023 \\
\hline $\begin{array}{c}\text { Facilities for } \\
\text { treatment of } \\
\text { waste gas }\end{array}$ & 0.768 & $\begin{array}{c}0.699 \\
9\end{array}$ & 0.812 & 0.981 & 1 & 0.023 \\
\hline $\begin{array}{l}\text { Facilities for } \\
\text { treatment of } \\
\text { waste water }\end{array}$ & 1 & 0.663 & $\begin{array}{c}0.688 \\
4\end{array}$ & $\begin{array}{c}0.819 \\
1\end{array}$ & 0.821 & 0.023 \\
\hline $\begin{array}{l}\text { The proportion } \\
\text { of natural } \\
\text { protection area }\end{array}$ & $\begin{array}{c}0.638 \\
9\end{array}$ & $\begin{array}{c}0.805 \\
6\end{array}$ & $\begin{array}{c}0.861 \\
1\end{array}$ & $\begin{array}{c}0.861 \\
1\end{array}$ & 1 & 0.061 \\
\hline Environmental & & & & & & \\
\hline $\begin{array}{l}\text { governance } \\
\text { investment }\end{array}$ & $\begin{array}{c}0.519 \\
7\end{array}$ & $\begin{array}{c}0.574 \\
8\end{array}$ & $\begin{array}{c}0.716 \\
5\end{array}$ & 1 & $\begin{array}{c}0.720 \\
5\end{array}$ & 0.128 \\
\hline proportion & & & & & & \\
\hline
\end{tabular}

\section{B. The Selection of Optimal Reference Sequence}

In view of the dimensionless, selecting the reference sequence:

$\mathrm{Xi}=(1,1,1, \ldots, 1) \quad(\mathrm{i}=1,2,3, \ldots, 19)$

C. Calculating the Absolute Difference Between the Reference Sequence and Compare Various, as Ahown in Table II, 
TABLE II. ABSOLUTE DIFFERENCE SEQUENCE

\begin{tabular}{|c|c|c|c|c|c|}
\hline Index & 2008 & 2009 & 2010 & 2011 & 2012 \\
\hline \multirow[t]{2}{*}{ Water resources } & 0.316 & 0.400 & 0.410 & 0.332 & \multirow[t]{2}{*}{0} \\
\hline & 3 & 4 & 2 & 5 & \\
\hline precipitation & 0.51 & 0.237 & 0.132 & 0.186 & 0 \\
\hline \multirow[t]{2}{*}{ Forest coverage } & 0.179 & 0.138 & 0.138 & \multirow[t]{2}{*}{0.037} & \multirow[t]{2}{*}{0} \\
\hline & 4 & 9 & 9 & & \\
\hline The fine weather & 0.047 & 0.017 & 0.008 & 0.002 & \multirow[t]{2}{*}{0} \\
\hline days & 1 & 6 & 8 & 9 & \\
\hline Natural gas & 0.154 & 0.181 & 0 & 0.073 & 0.122 \\
\hline Iron ore & 0 & 0.182 & 0.141 & 0.387 & 0.444 \\
\hline \multirow{2}{*}{ Population density } & \multirow[t]{2}{*}{0} & 0.005 & 0.028 & 0.033 & 0.041 \\
\hline & & 4 & 9 & 9 & 5 \\
\hline The per capita & 0.247 & 0.207 & 0.178 & \multirow{2}{*}{0} & \multirow[t]{2}{*}{0} \\
\hline water consumption & 2 & 3 & 8 & & \\
\hline & 0.039 & 0.026 & 0.012 & 0.009 & \multirow{2}{*}{0} \\
\hline $\begin{array}{l}\text { consumption } \\
\text { million GDP }\end{array}$ & 6 & 8 & 5 & 6 & \\
\hline \multirow{2}{*}{$\mathrm{SO}_{2}$ emissions } & 0.082 & 0.015 & \multirow[t]{2}{*}{0} & 0.126 & 0.079 \\
\hline & 5 & 2 & & 1 & 9 \\
\hline $\mathrm{NO}_{\mathrm{X}}$ emissions & 0.023 & 0 & 0.117 & 0.447 & 0.434 \\
\hline \multirow[t]{2}{*}{ soot emissions } & 0.056 & 0.019 & \multirow[t]{2}{*}{0} & 0.621 & 0.595 \\
\hline & 6 & 6 & & 9 & 4 \\
\hline The industrial solid & 0 & 0.100 & 0.376 & 0.561 & 0.566 \\
\hline emissions & & 4 & 1 & 9 & 2 \\
\hline waste water & \multirow[t]{2}{*}{0} & 0.090 & 0.150 & 0.199 & \multirow[t]{2}{*}{0.271} \\
\hline emissions & & 4 & 9 & 7 & \\
\hline The utilization of & 0.091 & \multirow[t]{2}{*}{0} & 0.201 & 0.412 & 0.463 \\
\hline solid waste & 1 & & 1 & 7 & 5 \\
\hline $\begin{array}{l}\text { Facilities for } \\
\text { treatment of waste }\end{array}$ & 0.232 & $\begin{array}{c}0.300 \\
1\end{array}$ & 0.188 & 0.019 & 0 \\
\hline \multicolumn{6}{|l|}{ gas } \\
\hline $\begin{array}{l}\text { Facilities for } \\
\text { treatment of }\end{array}$ & 0 & 0.337 & $\begin{array}{c}0.311 \\
6\end{array}$ & $\begin{array}{c}0.180 \\
9\end{array}$ & 0.179 \\
\hline \multicolumn{6}{|l|}{ waste water } \\
\hline & 0.361 & 0.194 & 0.138 & 0.138 & \multirow{2}{*}{0} \\
\hline $\begin{array}{c}\text { natural protection } \\
\text { area }\end{array}$ & 1 & 4 & 9 & 9 & \\
\hline \multicolumn{6}{|l|}{ Environmental } \\
\hline governance & 0.480 & 0.425 & 0.283 & \multirow{2}{*}{0} & 0.279 \\
\hline $\begin{array}{l}\text { investment } \\
\text { proportion }\end{array}$ & 3 & 2 & 5 & & 5 \\
\hline
\end{tabular}

D. The Calculation of Correlation Coefficient and Correlation Degree

According to the standardization of the parameter values in Table I and absolute difference in Table, it can calculate correlation coefficient of comparative column to reference column, and the overall weighted correlation degree for each year[7] ( table III)

TABLE III. THEECOLOGICAL ENVIRONMENT OF HEBEI PROVINCE SUSTAINABLE EVALUATION INDEXS' CORRELATION COEFFCIENT AND CORRELATION DEGREE

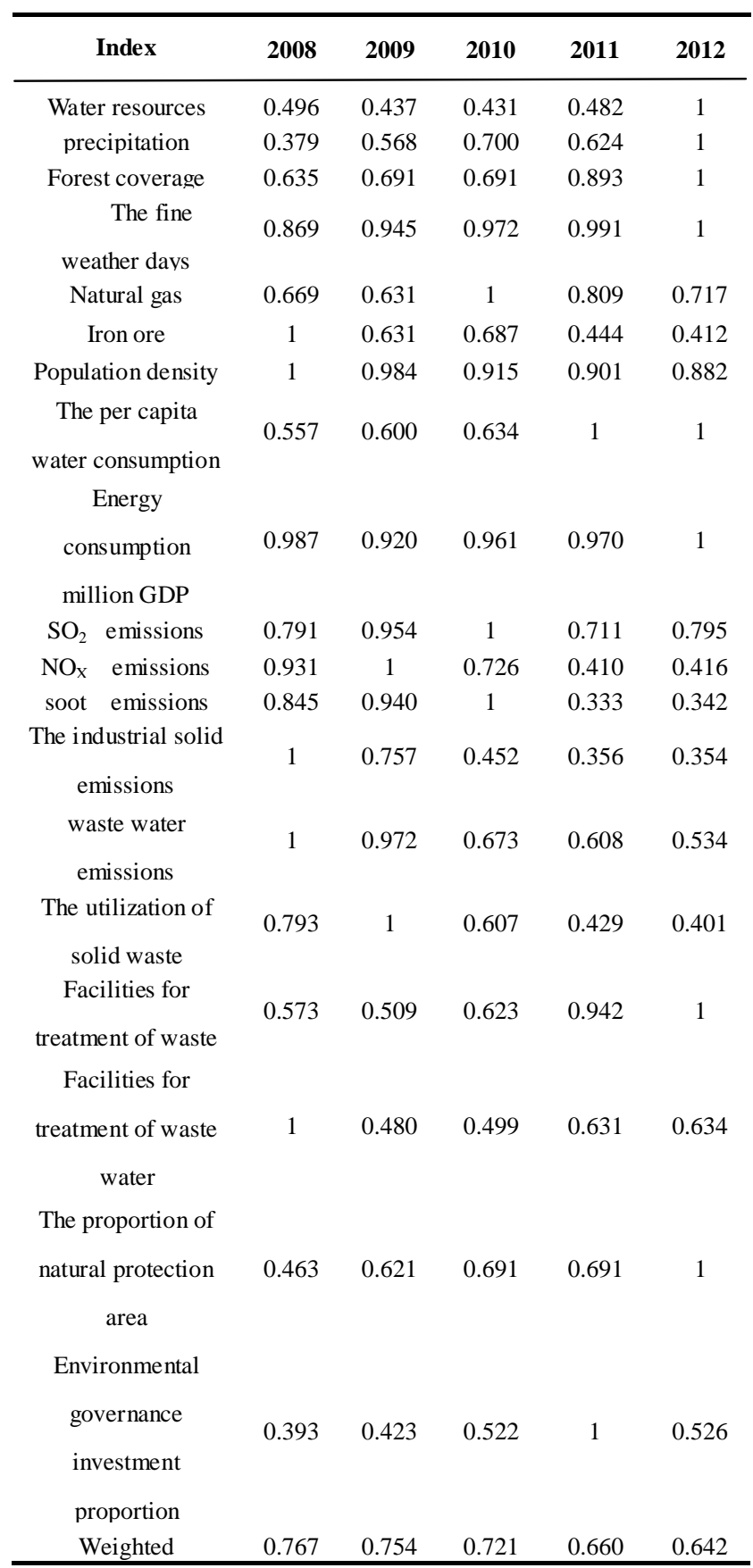

E. The Analysis and Discussion of Results

From the results of correlation (table III) of Hebei province in 2008-2012, it can be seen that the index system of overall weighted correlation degree is reduced year by year. In 2008, the weighted correlation degree was 
0.767 , and it had fallen to 0.642 by 2012 , which illustrates a low sustainable degree; it shows that the ecological environment in Hebei province is not sustainable.

According to the result of correlation coefficient transverse comparison, it can be seen in 2008 the correlation coefficients of these indexes,like precipitation, water resources, energy consumption million GDP, facilities for treatment of waste gas, the proportion of natural protection area and environmental governance investment proportion are lower, and far from the optimal value. These areas become the key to sustainable ecological environment in Hebei province.In 2009 these indexes' are still low; the correlation coefficient of indexes in 2010, especially NOX emissions, the industrial solid emissions, waste water emissions and the utilization of solid waste have reduced comparison with the two previous years. Although the proportion of natural protection area and environmental governance investment proportion's correlation coefficient increased slightly, it still made the correlation decline in 2010.In 2011 and 2012, natural gas, iron ore reserved and population increased, more importantly, the correlation coefficient of indicators that seriously affected air quality,such as SO2, NOx dust and industrial solid is small, and the utilization of rates solid waste and environmental governance investment proportion are very low.

Making the longitudinal comparison, 2008 - 2012, the correlation coefficients of forest coverage rate, the number of fine days reached or better than level two, energy consumption million GDP, waste gas treatment facilities and the proportion of natural protection area had increased, while NOx emissions, dust emissions, the utilization of solid waste, waste water emissions and the utilization of solid waste's correlation coefficient decreased year by year. Combined with the change trend of indicators system correlation decreasing year by year, it suggested that these factors be the key factors that affect the quality of the ecological environment. Therefore, human beings should focus on these aspects, improve the quality of the environment, promote the ecological environment sustainable development.

\section{COUNTERMEASURES AND SUGGESTIONS}

By the analysis of correlation coefficient and correlation degree about the indexes, people should make more efforts on the smaller and continue to maintain the larger aspects.Through the unremitting efforts, ecological environment sustainable development will be implemented. To this end, some following countermeasures are proposed:

In the northern area of China,water resources are a serious shortage,the South to North Water Diversion Project has become an important strategic initiatives to coordinate, allocate optimally water resources. Nevertheless whether transferred or local water is very precious, it must be reasonable development to work in the process of industrial and agricultural production and social life. Government departments should reinforce industrial project examination and approval system about the high water consumption to properly control industrial water, establish the water saving mechanism, introduce the effective policies and measures, and fully improve the efficiency of water using[10]; in addition, the agricultural water consumption is very large, although the new irrigation, drip irrigation has been proposed, in practice, the conventional irrigation agriculture still accounts the majority, the former understands the new technology little, and the government in this regard makes work less. Therefore, the government should make policy direction.In view of the use and cost of new technology, new equipment, the government should appoint some professional personnel to farmers to impart technology knowledge and give appropriate subsidies. So that, there is no longer any menace from the "rear"for farmers; in the region, cultivating drought tolerance crops is also a measure of water saving.

An important reason causing the deterioration of the ecological environment is the serious air pollution. So the air pollution governance should be based on the prevention and control of pollution of sulfur dioxide and nitrogen oxides, soot and vehicle exhaust, and strictly control the total atmospheric pollution. Promotion the power plant desulphurization, controlling the sulfur content of coal; active introducing and using of clean energy such as natural gas, ethanol; strict management of the vehicle in accordance with the requirements of environmental protection, promoting public transport and cycling mode. In addition, the adjustment and optimization of industrial structure and layout in the 
region,caring out comprehensive governance for the high energy consumption, heavy pollution enterprises are also necessary. By adjusting the energy structure, product structure, enhancing the level of equipment and technology upgrading, protecting environmental facilities, strengthening the smoke, dust, waste gas governance process, which does not meet the function positioning, does not conform to the industrial industry planning, environmental quality and the image of the city's industrial enterprises to conduct a comprehensive renovation, implement rectification within a time limit or forced migration, closed, to achieve comprehensive discharging standard of industrial enterprises.

In addition to the technical and institutional means can be also set out from the point of self purification capacity of the environment: plants can beautify the environment, regulate climate, intercept the dust, absorb harmful gases and other functions, it can also be in the range of large area, purify the atmosphere for a long time, continuously. Especially under the conditions of a widely influence scope and low concentration of pollutants in the atmosphere, purification of plant is an effective method. In the city and industrial district, expanding the green area is a long-term and comprehensive multifunctional measure for air pollution prevention and cure.

For some products or industries with serious waste problem, with the help of raw materials, production technology and product innovation,we can solve the pollution problem. Improvement of production management, to reduce the amount of wasting water of compressed water; reducing the consumption or full recovery of by-product of wasting water in order to reduce the concentration of wasting water; to strengthen management, to prevent the run, run, drip, drain, which will reduce the cost of wasting water treatment. Increase in the field of wasting water treatment facilities investment costs at the same time. The effective treatment for wasting water of protection and rational utilization of water resources can also play a role in promoting.
Citizen's environmental protection consciousness also plays an important role in the ecological construction, improving the environmental awareness of citizens contributes to the prevention of environmental problems from the source[11]. It is suggested that the government should set up environmental advocacy group, through seminars, issuing environmental materials to spread ecological environment knowledge, encourage people to actively participate in the environmental protection act. Through publicity and education to make people understand the relationship between human activities and environment. Set up the correct concept, and people will actively join the ranks of environmental protection. In addition,suggested that publicity stage should take quarter cycle.

\section{REFERENCE}

[1] Mei Jing, Zhaoqing.Synthetical evaluation of the regional eco-environment sustainability based on PSR model Jiangsu Province $[\mathrm{J}]$. Territory \& Natural Resources Study,2009,No2:65-67

[2] Zhao Duo,Lu Jianbo.The establishment of the ecological environment evaluation index system of sustainable development in zhejiang province [J].Environmental Pollution \& Control,2003,12(6)

[3] Zhang Pengtao,Shang Ling.Based on the ecological footprint model research of county ecological sustainable [J].Journal of Henan Agricultural Science,2014,43(5):82-87

[4] Wei Xia. Study on the carrying capacity of the ecological system of Hebei Province [D], 2013

[5] Zhao Xiangui, Xiaoling, Ma Caihong. Based on the ecologica footprint of the index system of sustainable development construction [J]. Scientia Agricultura Sinica, 2006, 39 (6) : 1202-1207.

[6] Zhao Xia, Kong Chuijing.A review of sustainability indicators of ecological environment at home and abroad [J].Journal of Northwest University, 2014,5 (3) : 136-145.

[7] Zhao Tao, Mi Guofang. The research of the ecological environment sustainable development evaluation model in Inner Mongolia[J]. Journal of Beijing Institute of Technology, 2012, $14(1): 28-31$.

[8]China Sustainable Development Strategy Research Institute, Chinese 2010 sustainable development strategy report -- green development and innovation[M]. Science Press, 2010 : 136-159.

[9] Huang Hui, Ma Junjie. Grey correlation method application in the analysis of ecological demonstration area construction sustainable development $[\mathrm{J}]$. Bulletin of soil and water conservation, 2005, 25 (2) : 48-52.

[10] Fan Hua, Study on ecological environment sustainable development in Northern Shaanxi based on the theory of eeological Footprint[D]. Beijing : Beijing Forestry University, 2010

[11] Guo Fumei. The sustainable development of regional ecological environment assessment in Leshan [D]. 2009 